\title{
O inquérito policial como instrumento do contraditório mitigado
}

\author{
Fabiano Silveira Pignata ${ }^{1}$
}

\begin{abstract}
Resumo: $\mathrm{O}$ inquérito policial é o instrumento que a polícia judiciária utiliza para subsidiar o titular da ação e para formar sua opinião sobre o delito, uma vez que este é de fundamental importância no deslinde de uma infinidade de crimes (contra a pessoa, o patrimônio, a economia popular, etc.), tendo como finalidade a solução dos crimes que assolam a paz social. O presente artigo busca discutir os reflexos críticos causados pela promulgação da Lei 13.245/16 no inquérito policial, com a possibilidade de aplicação do contraditório mitigado na fase pré-processual. Para isso, trará à baila a dinâmica da fase investigativa em um modelo inquisitorial brasileiro, a aplicação dos princípios constitucionais da ampla defesa e do contraditório no inquérito policial e a identificação das modificações causadas pela Lei 13.245/16 que alcançou o instituto do inquérito policial. A metodologia utilizada foi exploratória e qualitativa, tendo por base a revisão bibliográfica como procedimento técnico. Os resultados apresentados advêm da possibilidade da utilização do contraditório mitigado na fase pré-processual com a entrada em vigor da Lei 13.245/16 como atividade afirmativa e garantista do Estado na efetivação da defesa do suspeito/indiciado no procedimento investigativo.
\end{abstract}

Palavras-Chave: Inquérito Policial; Contraditório mitigado; Lei 13.245/16.

\begin{abstract}
The police investigation would be the instrument that the judicial police uses to subsidize the owner of the action and to form their opinion about the crime, given that it exercises fundamental importance in the delimitation of an infinite number of crimes (against the person, patrimony, popular economy, Etc.) with the purpose of solving the crimes that devastate the social peace. The present article seeks to discuss the critical reflexes caused by the promulgation of Law 13.245 / 16 in the Police Inquiry with the possibility of applying the Mitigated contradiction in the pre-procedural phase. To do so, the application of the constitutional principles of ample defense and contradiction in the police Inquiry and identification of the modifications caused by law 13245/16 that reached the institute of the Police Inquiry will be brought to the dynamics of the investigative phase in a Brazilian inquisitorial model. The methodology used was exploratory and qualitative, based on a bibliographical review as a technical procedure. The results presented come from the possibility of using the Mitigated contradiction in the pre-procedural phase with the entry into force of Law 13.245 / 16 as an affirmative activity and guarantor
\end{abstract}

\footnotetext{
${ }^{1}$ Delegado de Polícia Civil do Estado do Amazonas. Especialista em Direito Público e Ciências Penais. Mestrando no ProgramaProgramaProgramaProgramaprograma de Pós -Graduação em Ciência e Meio Ambiente da UFPA.
} 
of the State in effecting the defense of the suspect / indicted in the investigative procedure.

Key words: Police Inquiry. Mitigated contradiction. Law 13.245 / 16.

\section{Introdução}

O presente artigo busca discutir os reflexos críticos causados pela promulgação da Lei 13.245/16 no inquérito policial, com a possibilidade de aplicação do contraditório diferido na fase pré-processual. Para isso, será explicada a dinâmica da fase investigativa em um modelo inquisitorial brasileiro, a aplicação dos princípios constitucionais da ampla defesa e do contraditório no inquérito policial e a identificação das modificações causadas pela Lei 13.245/16 que alcançou o instituto do inquérito policial.

O primeiro capítulo abordará a fase pré-processual cotejando com as características do inquérito policial, um dos instrumentos utilizados no procedimento investigativo, discorrendo sobre sua sigilosidade e inquisitividade, mostrando que, apesar dessas características, a utilização de princípios fundamentais - dentre os quais a dignidade da pessoa humana, o devido processo legal, a presunção de inocência ou da não culpabilidade e o respeito ao contraditório (bilateralidade) e a ampla defesa assentados e resguardados na Magna Carta Brasileira - são possíveis e necessários para a sua efetividade na fase investigativa.

O segundo capítulo trará a abordagem tradicional e formal da aplicação do contraditório e da ampla defesa na fase investigativa, mostrando a visão de renomados autores acerca dos aspectos do tema, confirmando que tanto o contraditório quanto a ampla defesa não são assegurados no procedimento inquisitivo, contrariando os princípios naturais que transcendem a própria dignidade humana.

O terceiro capítulo desenvolve o cerne do artigo, que é a possibilidade do contraditório mitigado na fase investigativa, desde a entrada em vigor da Lei 13.245 de 12 de janeiro de 2016, que alterou os 
artigos $7^{\circ}$, XIV e XXI, “a”, $\S § 10,11$ e 12 da Lei n 8.906, de 4 de julho de 1994 (Estatuto da Ordem dos Advogados do Brasil), assegurando ao causídico a efetiva participação na fase pré-processual da persecução penal, inclusive com a possibilidade de apresentar quesitos e razões ao presidente do procedimento investigativo, desde que pertinente à infração apurada.

A discussão da alteração legislativa descrita neste artigo científico permite que seja ultrapassada a simples interpretação do contexto normativo, e, também, a reflexão sobre a necessidade de assegurar os aspectos defensivos do investigado na fase pré-processual, legitimando, assim, a atuação do advogado na fase que deslinde a futura ação penal, sob pena de ofensa ao ordenamento constitucional principiológico constitucional.

A metodologia utilizada foi exploratória e qualitativa, que identifica com maior familiaridade o problema explicitado, tendo por base como procedimento técnico, por meio de autores renomados no assunto abordado.

Assim, será demonstrado como a Lei no 13.245/16 trouxe o início da evolução ao sistema investigativo brasileiro por meio do contraditório mitigado, dado sua atuação no instituto do inquérito policial, prevendo procedimentos vanguardistas característicos da doutrina garantista.

\section{A fase pré-processual e o inquérito policial}

A investigação preliminar situa-se na fase pré-processual, o gênero do qual são espécies o inquérito policial, as comissões parlamentares de inquérito, as sindicâncias, etc. Assim, Lopes Jr (2017, p. 119-120) discorre que essa fase constitui em um entrelace de atividades desenvolvidas e concatenadas por órgãos essenciais do Estado, com base em uma notíciacrime, com caráter prévio e de natureza preparatória ao processo penal, e que pretende determinar a autoria e a materialidade de um fato aparentemente delituoso, com o objetivo de justificar ou não a ação penal. 
A persecução penal divide-se em fase pré-processual e processual, servindo como norteador a função punitiva do Estado. Pacelli (2017, p. 57) define, em poucas palavras, o objetivo da persecução criminal no direito penal brasileiro "como sendo dever do Estado, uma vez praticada a infração penal, cumpre inicialmente a ele, o esclarecimento, apuração e nuances do ilícito. Assim, prevê a Lei 12.830/13 que é precípua e privativa a função investigativa por parte do Estado.”

Nossa Carta Magna prevê, em seu art. 144, os órgãos responsáveis pela segurança pública estatal, que, por consequência, atuam de forma enfática na persecução penal, contudo cada órgão tem suas atribuições definidas no diploma constitucional e infraconstitucional. Para Pacelli (2017, p. 58), o Código de Processo Penal é um desses diplomas legais que define as atribuições de alguns órgãos responsáveis pela segurança pública estatal, frisando a atribuição da polícia judiciária na investigação da autoria e materialidade de crimes comuns.

De forma sucinta, a investigação criminal pode ser definida como o conjunto de atos do Estado voltado para a apuração da autoria e materialidade de uma infração penal, sendo essa função desempenhada pela polícia judiciária por intermédio do instrumento administrativo conhecido por inquérito policial (NICOLITT, 2014, p. 169).

A investigação policial e a elaboração do inquérito são tarefas complexas e que exigem conhecimento jurídico e prático, além do que a letra da lei explicita sobre os procedimentos de investigação preliminar ao processo penal. São necessários recursos interpessoais desenvolvidos por policiais civis, no sentido de superar dificuldades existentes, sejam elas pela falta de recursos materiais e humanos para a realização da investigação de todos os crimes que chegam ao conhecimento da Polícia Civil, ou pelas dificuldades de comunicação entre os diferentes operadores do Sistema de Justiça Penal. Michel Misse (2010, p. 95) explica bem esse fenômeno 
Saber fazer as conexões, conhecer as pessoas, entender relações, ter os contatos, poder vincular dados de pessoas e coisas de diferentes lugares, com processos e inquéritos, são um capital importante que gera informação valiosa.

Como bem colocado por Marcão (2014, p. 116), o inquérito policial não se destina à apuração de fatos direcionados, com vistas à confirmação de tese ou intuição da autoridade que preside, muito menos com circunstâncias preconcebidas em desconsideração ao todo que deverá ser investigado.

Em suma, quando é cometido um delito, deve o Estado, por intermédio da polícia civil, função repressiva, buscar elementos informativos acerca da autoria e da materialidade, subsidiar o titular da ação penal (Ministério Público ou ofendido), a fim de que este, apreciando-as, decida se oferece a denúncia ou queixa-crime. Oferecida a denúncia, o inquérito policial a acompanhará para que o magistrado avalie todas as circunstâncias do art. 395 do Código de Processo Penal, para recebe-la ou rejeitá-la. Caso seja recebida, o inquérito policial acompanhará a ação penal, ficando anexado aos autos. Por isso, atenta-se que o destinatário imediato do inquérito é o titular da ação (Ministério Público ou ofendido) e o destinatário mediato é o juiz.

O ilustre Pacelli (2017, p. 58) traz de forma brilhante o resumo da dinâmica pré-processual e a atribuição investigativa dos atores dessa matiz

[...] fase de investigação, portanto, em regra promovida pela polícia judiciária, tem natureza administrativa, sendo realizada anteriormente à provocação da jurisdição penal. Exatamente por isso se fala em fase pré-processual, tratando-se de procedimento tendente ao cabal e completo esclarecimento do caso penal, destinado, pois, à formação do convencimento (opinio delicti) do responsável pela acusação. O juiz, nessa fase, deve permanecer absolutamente alheio à qualidade da prova em curso, somente intervindo para tutelar violações ou ameaça de lesões a direitos e garantias individuais das partes, ou para, mediante provocação, resguardar a efetividade da função jurisdicional, quando, então, exercerá atos de natureza jurisdicional. 
Assim, o inquérito policial é o instrumento que a polícia judiciária utiliza para subsidiar o titular da ação e para formar sua opinião sobre o delito, uma vez que este é de fundamental importância no deslinde de uma infinidades de crimes (contra a pessoa, o patrimônio, a economia popular, etc.), tendo como finalidade a solução dos crimes que assolam a paz social. $\mathrm{O}$ Superior Tribunal de Justiça no julgado do RHC 10.785/SP (5 Turma-Rel. Min. Jorge Scartezzini-j. 02.10.2001-DJ 20.05.2002- p. 164) demonstra uma das características do inquérito policial. "O inquérito é um procedimento administrativo-informativo destinado a fornecer ao órgão da acusação o mínimo de elementos necessários à propositura da ação penal. Nele não se aplica princípio processual do contraditório.”

Eugênio Pacelli (2017, p. 61) traz conceitos e objetivos do inquérito policial como sendo atividade específica da polícia denominada judiciária, isto é, a Polícia Civil, no âmbito da Justiça Estadual, e a Polícia Federal, no caso da Justiça Federal, que têm por objetivo a apuração das infrações penais e de sua autoria (art. $4^{\circ}, \mathrm{CPP}$ ). A denominação de polícia judiciária explica-se em um universo em que não há a direção da investigação pelo Ministério Público ou subordinação entre as instituições, como é o caso do Brasil. Quem preside e conduz o inquérito policial é a autoridade policial, delegado de polícia, seja estadual ou federal, apenas eles, como é garantido no art. $2^{\circ}, \S 1^{\circ}$ da Lei $12.830 / 13$.

Sobre o ponto de vista conservador e tradicional, a fase investigativa sempre teve um viés inquisitivo, sigiloso e sem debates. Contudo, em uma visão garantista e contemporânea, tal acepção deve ser discutida, haja vista que se tornam exemplos comuns determinados elementos informativos produzidos nessa fase sob a égide do sistema inquisitivo, elementos esses não repetidos na fase judicial, tornando-se provas definitivas, vide o caso de certas perícias que não mais podem ser reproduzidas em juízo devido ao exaurimento do objeto, ocasionando a condenação ou absolvição do réu. Como bem pontua Nucci (2017, p. 52) acerca dos sistemas previstos no 
Processo Penal Brasileiro, quando acusa que se trata de demagogia dos defensores do sistema puramente acusatório, pois inadmitiriam a existência de um sistema inquisitivo. A persecução penal no Brasil, hoje, possui duas fases, sendo a primeira inquisitiva, sem ampla defesa e contraditório, contudo chegando a produzir provas definitivas contra o réu, e a outra fase acusatória, sob a presidência de um juiz togado e sob o manto da ampla defesa e contraditório.

Como Guilherme de Souza Nucci (2017, p. 52) bem explana, o instrumento do operador do direito na fase pré-processual é o inquérito policial que servirá para subsidiar o titular da ação penal em razão da materialidade e autoria delituosa.

o disposto no Código de Processo Penal, que prevê a colheita inicial da prova por meio do inquérito policial, presidido por um bacharel em Direito, que é o delegado, com todos os requisitos do sistema inquisitivo (sigilo, ausência de contraditório e ampla defesa, procedimento eminentemente escrito, impossibilidade de recusa do condutor da investigação, etc).

Convém ressaltar os pontuais ensinamentos de Eugênio Pacelli (2017, p. 59), quando discorre sobre as características e os princípios constitucionais que subsidiam o inquérito policial.

[...] o inquérito policial em suas características essenciais, cumpre trazer a lume questão das mais importantes, atinente à necessidade, ou não, do contraditório e da ampla defesa no âmbito da fase de investigação, pois do ponto de vista da jurisprudência nacional, o tema pode não despertar maiores indagações, estando ali assentada, como regra, a não aplicação dos citados princípios constitucionais à fase de investigação.

Até por ser um instrumento probatório, o inquérito policial possui um valor relativo e dispensável, porém indiscutivelmente utilitário, tanto que uma fase pré-processual calcada em um inquérito fundamentado, técnico e contundente gerará uma denúncia robusta e uma sentença criminal justa. Contudo, como bem afirma Noberto Avena (2017, p. 136), um 
inquérito policial frágil não tem o condão de macular toda uma ação penal, pois existem outras formas de se conseguir material probatório para se punir o infrator. Isso demonstra a independência formal do inquérito em relação ao processo criminal, pois com base nele, caso seja instaurado, sem, portanto, serem observadas, na sindicância policial, normas procedimentais estabelecidas para a realização de uma determinada diligência, a consequência não será a nulidade automática do processo, mas unicamente a redução do já minimizado valor probante que é atribuído ao inquérito. Nesse sentido, o STJ no RHC 21.170/RS, DJ 08.10.2007, reiterou decisões anteriores que compreenderam que eventuais máculas no procedimento policial não contaminam a ação penal superveniente, vez que aquele é mera peça informativa, produzida sem o crivo do contraditório.

Apesar de vozes contrárias à eficiência e à utilidade do inquérito policial, tal qual exemplificado nas proposituras na Câmara Federal do projeto de Lei 7.402/2014 apensado ao Projeto 5.776/2013, aquele prevendo a extinção do modelo investigativo atual e este regulamentando a atividade investigativa do Ministério Público, o inquérito mostra-se resiliente aos ataques dos céticos acerca da efetividade de tal instrumento, levando a crer que o problema da segurança pública se resolveria com a mudança do instrumento investigativo, simples falácias.

O inquérito policial, por sua natureza, acaba configurando um primeiro juízo do Estado acerca de um evento criminoso, uma vez que a versão ali explicitada tende a ser reproduzida na persecução penal, da denúncia do Ministério Público à formação da convicção pelo juiz. Na percepção de diferentes operadores do Sistema de Justiça Criminal, assim como uma "boa investigação", um "bom inquérito" é aquele que propicia a reconstituição de um delito de forma detalhada, "não deixando dúvidas" quanto aos elementos centrais (autoria, materialidade, motivação e circunstâncias). Para alguns delegados, "a prova da excelência de um 
inquérito está na confirmação das conclusões da investigação pelo veredito do juiz" (RATTON, 2010, p. 267).

Assim, o processualista penal moderno deve superar esse entendimento supra, pois as garantias individuais do suspeito ou indiciado, em um estado democrático, devem ser ressaltadas desde a fase préprocessual e superdimensionadas na fase judicial. Corroborando desse ideal, Pacelli (2017, p. 59) discorre sobre sua experiência nos anais científicos que tem participado, "parece crescente na doutrina brasileira, ao menos e em pesquisas e encontros acadêmicos (seminários, congressos, etc.), o entendimento segundo o qual a presença do contraditório no inquérito policial seria uma exigência constitucional."

\section{O contraditório e a ampla defesa na atividade investigativa}

Conforme preconiza, Silva (2016, p. 23-24) não vigora o princípio do contraditório na fase pré-processual, mas sim na fase processual estrita, se traduzindo tal princípio na necessidade da audiência bilateral e na permissividade em manifestar-se acerca da prova produzida pela parte contrária.

$\mathrm{Na}$ visão de Eugênio Pacelli (2017, p. 59-60), o princípio do contraditório na fase investigativa do ordenamento criminal brasileiro em vigor não teria como ser acolhido, embora a instauração de investigação criminal, por si só, já se imiscui no âmbito do espaço de cidadania plena do investigado, na constituição de sua dignidade pessoal e reputação social, além do evidente transtorno na sua tranquilidade. Não se poderia identificar um gravame que, sob a perspectiva do direito positivo, possa ser equiparado a uma punição ou sanção, mas caso fosse assim, não se hesitaria em exigir o efetivo exercício do contraditório e da ampla defesa nessa fase.

Nestor Tavora (2015, p. 116) enfatiza que a inquisitoriedade permite agilidade na atividade investigativa da polícia judiciária, otimizando a 
atuação da autoridade policial. Contudo, concorda com o fato de que como não há a participação do indiciado ou suspeito no transcorrer do procedimento por meio do uso do seu direito constitucional da ampla defesa e exercendo o contraditório, não pode o magistrado, na fase judicial, valer-se apenas de elementos informativos produzidos no inquérito para proferir sentença condenatória, pois incorreria em clara violação ao texto constitucional.

Para Ramos (2017), os inquéritos policial, civil ou administrativo são procedimentos inquisitivos que abarcam a coleta de informações e dados sem o manto do contraditório, sendo suprida essa supressão ou limitação do direito ao contraditório na fase judicial.

Tratando-se de um procedimento inquisitorial, destinado a angariar informações necessárias à elucidação de crimes, não há ampla defesa e contraditório no seu curso, mesmo entendendo existir um contraditório diferido, a novel legislação promulgada nos últimos tempos não foi capaz de alterar tal característica da fase investigativa.

[...] não afeta essa natureza inquisitiva a modificação determinada pela lei 13.245/2016 ao Estatuto da OAB (lei 8906/1994), que passou a estabelecer, no seu art. $7^{\circ}$, inciso XXI, como direito do Advogado "assistir a seus clientes investigados durante a apuração de infrações, sob pena de nulidade absoluta no respectivo interrogatório ou depoimento e, subsequentemente, de todos os elementos investigatórios e probatórios dele decorrentes ou derivados, direta ou indiretamente[...]" (AVENA, 2017, p. 135).

Em sua análise, Tourinho Filho (2008, p. 87) não admite a possibilidade da obrigatoriedade do contraditório na fase investigativa, enfatizando as características do inquérito como inquisitivo e não contraditório, no qual comparando com a aplicação desses institutos na fase judicial tornaria-se incompatível com a fase inquisitorial, visto que, no fórum, a presença de advogados é uma constante, o que não inviabilizaria o contraditório caso o causídico nomeado faltasse, pois seria imediatamente substituído por outro para assistir o interrogatório do réu, fato que não 
ocorreria nas delegacias pela escassez de advogados, e, por isso, não faria sentido a autoridade policial paralisar os trabalhos para tentar achar outro causídico para assumir a defesa do suspeito.

O Supremo Tribunal Federal já trazia em suas decisões a característica inquisitiva do inquérito policial levando a inaplicabilidade da garantia constitucional do contraditório e da ampla defesa, contudo, a preservação do direito fundamental do indiciado no inquérito de ser assistido por um advogado.

\begin{abstract}
Inaplicabilidade da garantida constitucional do contraditório e ampla defesa ao inquérito policial, que não é processo, porque não destinado a decidir litígio algum, ainda que na esfera administrativa; existência, não obstante, de direitos fundamentais do indiciado no inquérito, entre os quais o de fazer-se assistir por advogado, o de não se incriminar e o de manter-se em silencia. (RE 481.955-AgR, Rel. Min. Cármem Lúcia, julgamento em 10-5-2011, Primeira Turma, DJE de 5-2-2010)
\end{abstract}

Assim, trazendo um posicionamento mais áspero acerca da análise procedimental do inquérito policial, os sociólogos(as) Azevedo e Vasconcellos (2011, p. 61) discorrem sobre a característica do inquérito em formar culpa, apesar do seu caráter administrativo. Na prática, toma forma de uma préinstrução criminal, dominante na etapa judiciária, embora não garanta o contraditório e nem as garantias individuais do acusado. Nessa prática, o modelo do inquérito policial reforça um perfil burocrático e bacharelesco do seu condutor em detrimento das atividades investigativas. Levando a frente a alegação de que o problema seria a falta de estrutura, constata-se que, ainda que a estrutura fosse mais adequada, se poderia questionar o modelo atual pelas dificuldades de integração entre as polícias, o Ministério Público e o Judiciário como os alicerces do Sistema de Justiça Penal.

Apesar do exposto, o paradigma do contraditório na fase inquisitorial vem cedendo aos apelos garantistas, significando que se poderia começar a evidenciar a incidência dos princípios do contraditório e da ampla defesa durante a fase pré-processual, ainda que de forma mais tênue do que na fase 
processual. Apesar de parcela majoritária da doutrina reducionista e as próprias Cortes Superiores afirmarem no sentido de que os postulados não se aproveitariam na investigação preliminar, o próprio STF reconheceu a incidência flexibilizada das normas equidistantes ao editar a famigerada súmula vinculante 14: "é direito do defensor, no interesse do representado, ter acesso amplo aos elementos de prova que, já documentados em procedimento investigatório realizado por órgão com competência de polícia judiciária, digam respeito ao exercício do direito de defesa.”

Corroborando com nossa dialética, Pacelli (2017, p. 60) deixa-se seduzir pela tese garantista do direito criminal contemporâneo:

\footnotetext{
Ver o contraditório na fase de investigação, em tese, pode até se revelar muito útil, na medida em que muitas ações penais poderiam ser evitadas pela intervenção da defesa, com a apresentação e/ou indicação de material probatório suficiente a infirmar o juízo de valor emanado da autoridade policial ou do Ministério Público por ocasião da instauração da investigação.
}

Assim, trazer o contraditório mitigado para a fase inquisitorial é assumir maiores responsabilidades sociais e jurídicas no enfrentamento da criminalidade, além de outros dissabores, tal como o risco, evidente e concreto, da perturbação da regular tramitação da investigação pela intervenção técnica protelatória. Não há como recusar essa realidade, se bem examinadas as coisas no cotidiano de nosso judiciário. (PACELLI, 2017, p. 60)

\section{O contraditório mitigado na fase investigativa sob a égide da lei $13.245 / 16$}

Em que pese inquisitivo, admite-se que o investigado/indiciado indique ou solicite a juntada de provas ou documentos com o fito de comprovar suas alegações. A efetiva produção da prova requerida ou a juntada de documentos solicitada pelo investigado/indiciado está na esfera da discricionariedade da autoridade policial, que pode julgá-las irrelevantes ou 
protelatórias. Em um caso ou em outro (admissão da prova ou rejeição desta), deve o delegado despachar de forma fundamentada (SILVA, 2016, p. 24).

Há muito tempo, prevendo e admitindo a possibilidade de defesa na fase inquisitorial, Saad (2004, p. 221-222) aduzia que se não se mostrasse apropriado falar em contraditório no curso do inquérito policial - seja porque não existiria acusação formal, seja porque, na opinião de alguns, sequer haveria procedimento - não se poderia afirmar que não se admite o exercício do direito de defesa, porque esta teria lugar em todos os crimes e em qualquer tempo e estado da causa, e se trataria de oposição ou resistência à imputação informal, pela ocorrência de lesão ou ameaça de lesão.

A introdução do contraditório na fase pré-processual traduziria um reforço à garantia da preservação dos direitos humanos nessa fase, considerando que a preservação desses direitos é essencial para a manutenção de uma investigação eficaz e isenta. Assim, Nucci (2016) enfatiza a inadmissibilidade em um estado democrático de direito, a deliberada infringência dos direitos humanos em nome de uma pretensa segurança pública, mostrando à sociedade a inadequação dos abusos policiais e práticas não ortodoxas, como indispensáveis para trazer a paz e o sossego social.

De forma brilhante, Didier Jr. (2009, p. 100) explica a essência do contraditório no processo civil, conceitos que podem ser remetidos à práxis na persecução criminal, inclusive em sua fase pré-processual.

Há contraditório, por exemplo, na jurisdição voluntária. Contraditório é o direito de participar de um procedimento que lhe possa trazer alguma espécie de repercussão jurídica; não tem como pressuposto a existência de partes adversárias. Se há possibilidade de defesa, é porque há exercício do contraditório; se eu me defendo, estou participando do procedimento; estou, portanto, exercitando o meu direito de participação.

Os conceitos da enfática participação do suspeito na fase investigativa legitimando as ações de seu causídico já tinha seus adeptos 
mesmo antes da promulgação da Lei 13.245/16, que trouxe uma ratificação do pensamento dos autores que adotavam a corrente minimalista acerca do tormentoso tema do contraditório investigativo. Saad (2004, p. 221-222) já diferenciava as formas de exercer o direito de defesa na fase inquisitorial, trazendo o exercício exógeno que era o manejo de técnica paralela ao inquérito policial por meio do ajuizamento, por exemplo, de habeas corpus com o fito de trancar a investigação preliminar, ou, ainda, o exercício endógeno que se traduzia nos atos praticados dentro do inquérito (requerimento de diligências à autoridade policial, declarações do acusado e intervenção do causídico para manter as garantias individuais) pelo advogado, tudo isso para demonstrar que já existia essa tendência de introdução do contraditório na fase investigativa.

Não se pode negar que o novel diploma legislativo trouxe uma evolução do caráter garantista do sistema pré-processual brasileiro, em que o investigado, a vítima e a sociedade passam a ser vistos como sujeitos de direitos. O Estado na sua sanha de perseguir o jus puniedi do suspeito não deve permitir que direitos humanos básicos do indivíduo sejam infringidos, justamente, por quem deveria tutelá-los. Assim, essa alteração estatutária foi fundamental para garantir o respeito do direito à defesa justa durante a investigação. "[...] o direito do investigado/indiciado de se fazer acompanhar por advogado ou defensor público é evidente. O que não se exige é a indispensabilidade da presença do causídico.” (SILVA, 2016, p. 24). Nesse tocante, é importante a análise do inciso XXI, do artigo $7^{\circ}$ do EOAB, inserido pela Lei 13.245/16:

Art. $7^{\circ}$ São direitos do advogado:

$[\ldots]$

XXI - assistir a seus clientes investigados durante a apuração de infrações, sob pena de nulidade absoluta do respectivo interrogatório ou depoimento e, subsequentemente, de todos os elementos investigatórios e probatórios dele decorrentes ou derivados, direta ou 
indiretamente, podendo, inclusive, no curso da respectiva apuração: (Incluído pela Lei ${ }^{\circ} 13.245$, de 2016).

apresentar razões e quesitos; (Incluído pela Lei n ${ }^{\circ} 13.245$, de 2016).

A leitura do dispositivo deixa claro que é direito do advogado assistir seu cliente no bojo do procedimento investigativo criminal e a autoridade que preside o feito deverá conceder as condições necessárias ao causídico, agora constituído nos autos, para o satisfatório desempenho da defesa do investigado. O novel direito não pode ser confundido com a necessidade de presença obrigatória de advogado em toda e qualquer oitiva na seara policial. O investigado/indiciado tem direito como dito supra, de constituir, se quiser, advogado. Uma vez constituído, a autoridade policial não pode impedir que o causídico acompanhe seu cliente na oitiva, sob pena de nulidade absoluta do ato, nos termos do dispositivo acima transcrito. É preciso salientar ainda que caso o cidadão seja investigado em mais de um procedimento, será necessário demonstrar a constituição de advogado em cada um dos feitos (caso tencione-se a obrigatória participação do causídico em todos os apuratórios). (SILVA, 2016, p.24)

Assim, a mudança estatutária causada pela Lei 13.245/16 trouxe importante manutenção das garantias individuais na fase investigativa, seja para o advogado, seja para a autoridade que a preside. Apesar dessa alteração ter afetado apenas a Lei 8.906/94 que rege a carreira da advocacia, é inegável que o avanço da imprescindibilidade da presença do advogado quando requerido pelo cliente nessa fase, traz ares de mudanças de paradigmas em relação ao contraditório nos procedimentos preparatórios à ação penal. Assim, Avena (2017, p. 143) expõe sobre a mudança dos dispositivos alterados pela novel legislação.

[...] a alteração determinada pela lei 13.245/2016 incidiu apenas sobre o Estatuto da Advocacia, contemplando como direito do advogado o de assistir o investigado no curso da investigação criminal (inquérito policial, investigação do Ministério Público, etc). O legislador não alterou, portanto, o Código de Processo Penal 
ou qualquer outra lei processual penal especial, o que teria providenciado caso fosse sua intenção a de assegurar ampla defesa e contraditório em fase investigativa.

Corroborando com os argumentos supra, os autores Brito, Fabretti e Lima (2015, p. 78) relatam a importância da participação do advogado na fase investigativa, inclusive no interrogatório do suspeito ou indiciado, que deverá ser revestido de formalidades que visem a garantir os direitos fundamentais do preso, nesse interim, deve-se obedecer a previsão legal da presença do causídico.

A importância maior da Lei 13.245/2016 não está em garantir ao investigado o direito de ser assistido por advogado durante a investigação, mas sim em assegurar a prerrogativa do advogado por ele constituído em realizar essa assistência, pois esse direito decorre da interpretação sistemática da Constituição Federal e, inclusive, quanto ao investigado preso, traz a regra expressa de seu art. $5^{\circ}$, LXIII. A relevância da lei está no estabelecimento de sanção ao ato da autoridade que preside a investigação que obste à mencionada assistência, qual seja, a nulidade absoluta do respectivo interrogatório ou depoimento e, subsequentemente, de todos os elementos investigatórios e probatórios dele decorrentes ou derivados, direta ou indiretamente (AVENA, 2017, p. 143). Afinal, a alteração legislativa não modificou o Código de Processo Penal de modo a estabelecer a obrigatoriedade da assistência do advogado ao investigado durante o inquérito. No entanto, não foi isso que fez o legislador, o que fez foi assegurar o direito do advogado em assisti-lo, não podendo esse direito, quando requerido o seu exercício, ser obstado sob pena de nulidade do interrogatório, do depoimento e de todos os atos que daí decorrerem. (AVENA, 2017, p. 135).

Não contradiz o entendimento de que persiste a natureza inquisitorial do inquérito, a possibilidade conferida ao causídico pelo art. $7^{\circ}$, XXI, alínea a, da Lei 8.906/1994 de “apresentar razões e quesitos”. Isso é 
uma faculdade apenas, que deve ser exercida espontaneamente pelo advogado, caso entenda necessário.

Evidente que para a autoridade que preside a investigação não existe a obrigatoriedade de notificar o causídico para apresentar quesitos, uma vez que é ilegal a autoridade impedir a juntada das manifestações do advogado nos autos do inquérito. Não restou afetada, assim, a regra do art. 14 do Código de Processo Penal, que confere ao delegado de polícia o poder de indeferir eventuais diligências requeridas. Mas, é preciso atenção: sem embargo dessa previsão legislativa, o Superior Tribunal de Justiça no HC 69.405/SP, 6 Turma, DJ 25.02.2008, concedeu a ordem com a finalidade de determinar à autoridade policial o atendimento de diligências requeridas pelo ofendido ou pelo investigado, quando pertinentes e relevantes a elucidação do fato. Assim, considera-se, nessas hipóteses, que o próprio art. 14 do CPP faculta a esses interessados tais requerimentos, muito embora conforme preleciona Avena (2017, p.143), o deferimento ou não das providências requeridas fica a critério da autoridade policial, isto é "não haverá de constituir empecilho a que se garantam direitos sensíveis do ofendido, do indiciado, alcançando-se, então, por meio do Poder Judiciário, a determinação para que o delegado de polícia realize a medida pretendida em face de sua pertinência com a situação investigada”.

O posicionamento de Silva $(2016$, p.24) é no sentido de uma mitigação do contraditório na fase investigativa, considerando-se o poder decisório e discricionário, fundamentado na lei, da autoridade que preside o feito quando na aceitação ou na negativa das diligências ou quesitos interpelados pelo advogado, levando a uma maior liberdade de atuação e participação do causídico nessa fase.

No curso das oitivas, fica claro que o advogado poderá apresentar razões (eventual petição explicitando a versão do seu cliente e indicando meios probantes que sustentem - a efetiva materialização das diligências solicitadas pelo causídico, como já desenhado supra, será decidida fundamentadamente pelo 
delegado) e quesitos (sugestiono que o delegado faça as perguntas que entender pertinentes ao esclarecimento dos fatos e, ao final, permita que o advogado formule quesitos a seu cliente - caso a autoridade policial entenda que alguma pergunta é impertinente, pode indeferir a mesma, fazendo constar os motivos no termo).

A participação do causídico na defesa dos interesses do investigado/indiciado no curso do procedimento investigativo empresta fundamental importância diante o grau de confiabilidade dos elementos informativos coletados. A presença de advogado/defensor público nos atos praticados no procedimento investigativo afasta posteriores indagações acerca do vilipêndio à integridade física/psíquica do investigado/indiciado, fato esse muito corriqueiro na fase judicial durante a alegação da defesa no intuito de desconstituir eventual confissão na fase policial. (SILVA, 2016, p. 25)

A presença do causídico deve ser a premissa básica na fase investigativa, embora a evolução do Direito Processual Penal garantista e contemporâneo deva prevalecer diante da característica inquisitorial dessa fase. Assim, encontra-se positivada a questão do acesso do causídico aos autos do procedimento investigatório, mais uma vez, primando pela dignidade do investigado. Não se pode conceber, ainda, o amplo acesso irrestrito à investigação com fulcro na questão do contraditório mitigado. Pacelli (2017, p. 67) entende, portanto, que, embora o exercício da advocacia seja mesmo indispensável à defesa dos interesses de quem se acha submetido à persecução penal - entenda-se fase pré-processual, podendo o advogado, como regra, ter acesso aos autos do inquérito policial -, o fato é que, se a investigação assim o exigir, será perfeitamente aceitável a restrição ao aludido acesso, quando for a hipótese de levantamento de elementos informativos ainda não materializada nos autos do procedimento investigatório.

Corroborando com a tese supra, o Superior Tribunal de Justiça tem entendido que o direito à informação do investigado por meio do causídico 
aos autos do Inquérito Policial não deve ser irrestrito, devendo ser cotejado com as garantias constitucionais de terceiros.

\begin{abstract}
o acesso conferido aos procuradores não é irrestrito, restringindo-se aos documentos já disponibilizados nos autos que ser refiram apenas ao cliente específico, sendo vedado o acesso a dados pertinentes a outras pessoas. A concessão sem quaisquer reservas ofenderia o direito de terceiros à intimidade e à inviolabilidade de sua vida privada e prejudicaria a satisfatória elucidação dos fatos supostamente criminosos ainda em apuração. (HC n $\mathrm{n}^{0}$ 65303/PR, Rel. Min. Arnaldo Esteves Lima, $5^{\text {a }}$ turma, DJ de 20.5.2008)
\end{abstract}

É, também, questão debatida e consolidada no Supremo Tribunal Federal por meio da súmula vinculante 14, acerca do acesso do advogado ao procedimento investigativo." $E$ direito do defensor, no interesse do representado, ter acesso amplo aos elementos de prova que, já documentados em procedimentos investigatório realizado por órgão com competência de polícia judiciária, digam respeito ao exercício do direito de defesa."

Com base no exposto, percebe-se que a Lei 13.245/16 modificou a atuação do causídico e por conseguinte da autoridade que preside o feito investigativo, tendo-se em vista que sempre foi uma batalha dos advogados ter voz ativa e proatividade no contexto das investigações, principalmente quando da realização de oitivas. Comumente, os advogados queriam expor razões ao presidente das investigações, bem como fazer questionamentos a seus clientes durante o interrogatório, e acabavam sendo silenciados, sob o argumento de que não deveriam interferir no curso da oitiva. Concretamente, esse parece ser um dos cernes de tal dispositivo, o qual permite ao defensor apresentar razões e quesitos nesse contexto, melhorando a assistência prestada ao cliente nessa fase, além de justificar fatos e formular perguntas, desde que pertinentes, que auxiliem na apuração dos fatos. Assim, trazendo um ar de contraditoriedade ao procedimento eminentemente inquisitivo. 


\section{Conclusão}

Parte-se da premissa que a Carta Magna tem como finalidade precípua a garantia dos direitos fundamentais do indivíduo, e a Lei 13.245/16 demonstrou que essa ideia deve permear toda a persecução penal, inclusive a fase investigativa, e que seja instrumentalizada pelo inquérito policial, procedimento investigatório criminal, comissão parlamentar de inquérito, etc.

Pode-se afirmar que, mesmo com as alterações promovidas pela Lei 13.245/2016, as investigações criminais continuam com suas características inquisitivas, contudo, o indiciado possui a prerrogativa imanente de constituir um causídico nessa fase, e caso ocorra, será obrigatório o presidente do feito investigativo aguardar a presença do advogado para acompanhamento de seu cliente, assim, dando uma roupagem garantista e defensiva à fase pré-processual, apesar de todo o procedimento continuar concentrado na mão de uma única autoridade.

A nova redação do Estatuto da $\mathrm{OAB}$, dada pelo novel diploma legal, muito embora não tenha promovido uma revolução na fase pré-processual, ressaltou que a presença do advogado é de fundamental importância em toda a persecução penal, até mesmo na fase inquisitorial, atuando como mais uma garantia de credibilidade do procedimento policial.

No transcorrer desse artigo científico, abordou-se a fase investigativa e as características do inquérito policial e outros instrumentos investigativos trazendo um cotejamento entre a dinâmica dos instrumentos investigatórios e o estado democrático de direito com fundamento na Constituição Federal. Enfrentou-se o tema da ampla defesa e do contraditório no inquérito policial tendo como escopo o investigado e seus direitos individuas que deve ser a premissa de um sistema acusatório, seja na fase pré-processual ou judicial. 
A abordagem correta é que a novel legislação, Lei $\mathrm{n}^{0}$ 13.245/16, ampliou os direitos dos causídicos e a estrita obediência do presidente da investigação aos conceitos trazidos pela inovação legislativa e, consequentemente, resguardou as garantias fundamentais individuais do investigado. De mais a mais, a prerrogativa do advogado de acesso aos procedimentos investigatórios ou policiais não são vantagens indevidas, ilícitas, privilégios ou favores, e sim, efetivo respeito à administração da justiça, do direito de defesa e do contraditório de todo cidadão na fase préprocessual.

Em suma, a Lei $n^{0}$ 13.245/16 constitui um marco e um avanço para a investigação criminal, modernizando a forma de abordagem no inquérito policial, trazendo ao investigado uma maior transparência e democratização aos atos praticados, haja vista a obrigatoriedade do acompanhamento pelo causídico, desde que habilitado nos autos nessa fase da persecução penal, exercendo, assim, seu mister com dignidade e profissionalismo, indispensável ao bom andamento da justiça.

\section{Referências}

AVEnA, Norberto Cláudio Pâncaro. Processo Penal. 9ªed. Rio de Janeiro: Método, 2017

AZEVEDO, Rodrigo Ghiringhelli de; VASCONCELLOS, Fernanda Bestetti de. O inquérito policial em questão: situação atual e a percepção dos delegados de polícia sobre as fragilidades do modelo Brasileiro de investigação criminal. Sociedade e Estado, v.26, $\mathrm{n}^{0} 1$, p. 59-75, abr. 2011. Disponível em: http://search.scielo.org/?q=contradit\%EF\%BF\%BDrio+inqu\%EF\%BF\%BDrito+policial \&lang $=$ pt\&count $=15 \&$ from $=0 \&$ output=site \&sort=\&format=summary $\& \mathrm{fb}=\&$ page $=1 \&$ $\mathrm{q}=\mathrm{inqu} \% \mathrm{C3} \%$ A9rito+policial\&lang=pt\&page=1>. Acesso em: 27 jul. 2017

BRASIL. Constituição da República Federativa do Brasil. Brasília: Senado Federal,1988

Decreto-Lei 3689 de 3 de outubro de 1941. Institui o Código de Processo Penal. Diário Oficial da União, Rio de Janeiro, RJ, 3 out. 1941

. Lei 8906 de 4 de julho de 1994. Dispõe sobre o Estatuto da Advocacia e a Ordem dos Advogados do Brasil (OAB). Diário Oficial da União, Brasília, DF, 4 jul. 1994

Lei 12.830 de 20 de junho de 2013. Dispõe sobre a investigação criminal conduzida pelo delegado de polícia. Diário Oficial da União, Brasília, DF, 20 jun. 2013 
BRASIL. Lei 13.245 de 12 de janeiro de 2016. Altera o art. $7^{\circ}$ da lei $n^{\circ} 8906$ de 4 de julho de 1994 (Estatuto da Ordem dos Advogados do Brasil). Diário Oficial da União, Brasília, DF, 12 de jan. 2016

BRITO, Alexis Couto de; FABRETTI, Humberto Barrionuevo; LIMA, Marco Antônio Ferreira. Processo penal brasileiro. $3^{\mathrm{a}}$ ed, São Paulo: Atlas, 2015

CASTRO, Henrique Hoffmann Monteiro de. Lei 13.245/16 e a participação do advogado no inquérito policial. Disponível em: $\leq$ https://henriquehmc.jusbrasil.com.br/artigos/297334598/lei-13245-16-e-aparticipacao-do-advogado-no-inquerito-policial> Acesso em: 26 jul. 2017.

DIDIER JR., Fredie. Curso de direito processual civil. 11.ed. Salvador: Juspodivm, 2009

PACELLI, Eugênio. Curso de Processo Penal. 21ed. São Paulo: Atlas, 2017

LOPES JUNIOR, Aury. Direito Processual Penal. 14 ed. São Paulo: Saraiva, 2017

MARCÃO, Renato. Curso de processo penal. São Paulo: Saraiva, 2014

MISSE, Michel. Introdução" in Michel Misse. O inquérito policial no Brasil: Uma pesquisa empírica. Rio de Janeiro: NECVU/IFCS/UFRJ, Booklink. 2010

"O inquérito policial no Rio de Janeiro: Mudanças recentes, alcances, tradições e especificações" in Michel Misse,O inquérito policial no Brasil: Uma pesquisa empírica. Rio de Janeiro: NECVU/IFCS/UFRJ, Booklink. 2010

NICOLITT, André Luiz. Manual de processo penal. $5^{\text {a }}$ ed. São Paulo: editora Revista dos Tribunais, 2014

NUCCI, Guilherme de Souza. Código de Processo Penal comentado. 16 a ed. Rio de Janeiro: Forense, 2017

Guilherme de Souza. Direitos humanos versus segurança pública. Rio de Janeiro: Forense, 2016

RAMOS, André de Carvalho. Curso de direitos humanos. $4^{\mathrm{a} e d}$. São Paulo: Saraiva, 2017

RATTON, José Luiz et al "Refletindo sobre o inquérito policial na cidade do Recife: uma pesquisa empírica" in Michel Misse, $O$ inquérito policial no Brasil: Uma pesquisa empírica. Rio de Janeiro: NECVU/IFCS/UFRJ, Booklink, 2010

SAAD, Marta. O direito de defesa no inquérito policial. São Paulo: RT, 2004

SILVA, Márcio Alberto Gomes. Inquérito Policial: uma análise jurídica e prática da fase pré-processual. $3^{\mathrm{a}}$.ed. São Paulo: Millennium Editora, 2016

STF. RE 481.955-AgR, Rel. Min. Cármem Lúcia, julgamento em 10-5-2011

STJ. HC n ${ }^{0}$ 65303/PR, Rel. Min. Arnaldo Esteves Lima, $5^{\text {a }}$ turma, DJ de 20.5.2008

TÁVORA, Nestor; ALENCAR, Rosmar Rodrigues. Curso de direito processual penal. 10ªd. São Paulo: Juspodivm, 2015

TOURINHO FILHO, Fernando da Costa. Manual de processo penal. $10^{\mathrm{a}}$ ed. rev. e atual. São Paulo: Saraiva, 2008 